\title{
Exports and Innovation in Malaysia: the Role of Heterogeneity
}

\section{YuanFang Chen, Lim Thye Goh*}

University of Malaya, Malaysia

*ltgoh@um.edu.my

\begin{tabular}{l}
\hline Article Info \\
\hline Received : 2020-11-08 \\
Accepted : 2021-03-04 \\
Published : 2021-03-04 \\
\hline
\end{tabular}

Key words: innovation, export, heterogeneity

Abstract
The objective of this paper was to empirically examine the impact of
exports on the level of innovation in the manufacturing sector of
Malaysia and to focus on the role of heterogeneity in exports by
using detailed industry-level cross-sectional data on Malaysia's
manufacturing sector in 2014 . Utilizing the CDM model, as
postulated by Crepon, Duguet \& Mairesse (1998), this paper
investigated whether exporting to more countries, exporting greater
volumes, and exporting greater volumes to high-income countries
induced industry to increase its level of innovation. Estimates from
the CDM model showed, overall, a positive impact of exports on
innovation, more specifically, heterogeneity in exports mattered to
industries' innovating in the manufacturing sector in Malaysia.
Additionally, exporting to additional foreign destinations, exporting
greater volumes of product, and exporting more products to low-
income countries, especially to South Asian and Southeast Asian
countries, had a significant influence on inducing industries to
engage in innovation activities.

\section{INTRODUCTION}

In both business and economics, innovation can be a catalyst for growth. Innovation increases the likelihood of business success, and an innovative country will demonstrate increased productivity and performance. Moreover, innovation is one of the factors that seem to be highly distinguishable between successful and less successful firms. The current rapid development of technology, increasingly fierce global competition and the shortening life cycles of products has increased the pressure on companies to innovate. Innovation is an instruction to introduce new ideas and, or products to the market. These new ideas lead to reducing costs, introducing faster or better processing systems, improving organizational structures and networks, and developing new systems. Therefore, it is not suprising that in terms of output (productivity and quality), profitability and growth, innovative companies and countries perform better than those that lack innovation.

Malaysia, as a developing nation, has been investing heavily on innovation activities over the past two decades. Moreover, innovations, political stability, foreign direct investment inflows and export-oriented industrialization were among those factors that successfully transformed the country into a middle and high-income country. By 2014, Malaysia's population had reached 29.2 million, and its GDP per capita, based on purchasing power parity, was US $\$ 17,748$. It can be seen from the improvement of Malaysia's Global Innovation Index (GII) score relative to the GDP that the country achieved major innovation achievement during the period 2011-2014. Besides, the outstanding innovation performance of Malaysia enabled it to obtain the highest GII record out of all of the countries with the same income level in 2014. Malaysia ranked 33rd in the 2014 GII, slightly lower than its 31st ranking in 2011. Malaysia's rankings, in terms of innovation input, were 30th and innovation output was $35^{\text {th }}$ in 2014. 
Malaysia's governmental support for innovation has mainly come from its science, technology and innovation policies which were introduced and have been implemented since the 1980s. The government's increasing attention to research funding has helped stimulate the growth of innovation input and output, which is reflected in the rising proportion of R\&D expenditure in the GDP. As can be seen from Figure 1.1, the Gross Expenditure on Research and Development (GERD) is used to measure the current expenditure and capital expenditure on R\&D and it is compared with the national GDP as one of the indicators of scientific and technological progress or development (World Bank, 2016). Over the six years before 2014, the level of the GERD increased from RM6.071 billion in 2008 to RM13.972 billion in 2014. This was reflected in the levels of current expenditure (increased from RM5.134 billion to RM10.265 billion) and capital expenditure (increased from RM937 million to RM3.707 billion) from 2008 to 2014. Therefore, the share of the GERD in the GDP increased from $0.79 \%$ in 2008 to $1.26 \%$ in 2014. This showed that since 2008, the average annual growth rate was $14.90 \%$, which was consistent with the national key economic area's (NKEA's) support for innovation-led growth.

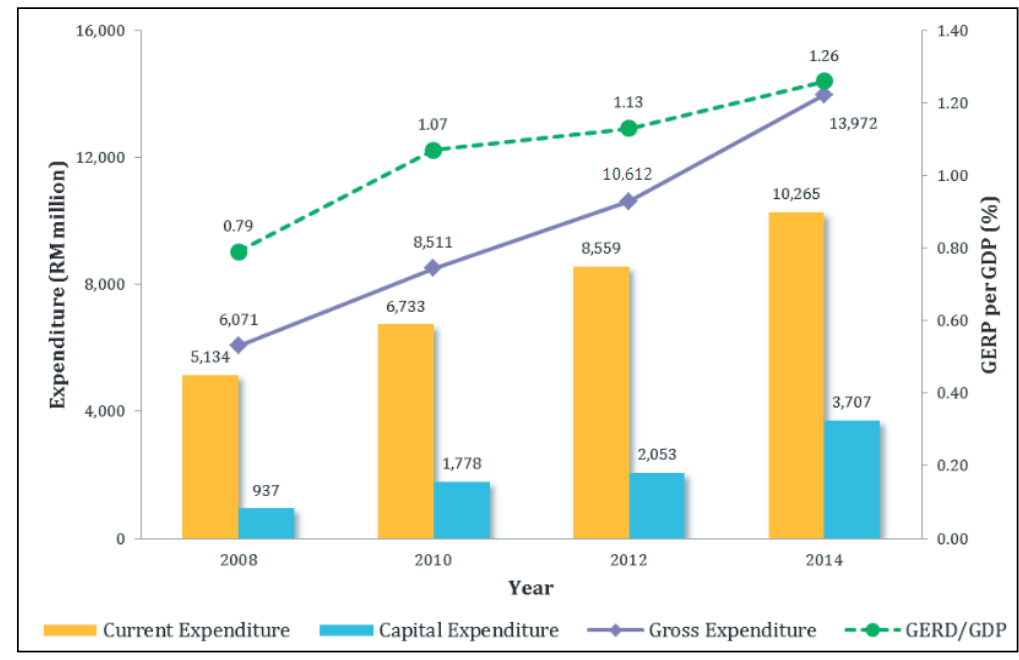

Source: National Survey of Research and Development $(R \& D) 2015$

Figure 1.1: Gross Expenditure on Research and Development, 2008-2014

As a leader in innovation, Malaysia is an outstanding example for other high- and middle-income countries, as it has performed well in the fields of innovative exports and commercialization. (Rajah \& Yap, 2015). Moreover, in the face of rapid globalisation, innovation has been a crucial factor in maintaining Malaysia's competitiveness. Considering the innovation performance in Malaysia to date, it is necessary to further improve the nation's innovation capacity, especially considering the progress made by other countries in the region in the field of innovation. Therefore, it is worth focusing on the question of how can Malaysia's innovation capability be improved.

On the other hand, from the context of trade liberalization, many developing countries have commenced trade liberalization plans and adopted export-oriented strategies to stimulate economic growth. Empirical findings from many countries have indicated that firms which export are more productive than non-exporting firms, and this relationship has been driven by producers becoming exporters. Many scholars believe that exporters will often obtain various knowledge inputs that are not available from the domestic market. Therefore, competition in foreign markets can enable exporting firms to accumulate both technological and market information, and this information can spill back to the local firm. This form of learning can 
promote a firm's' level of innovation. Hence, there seems to have a positive correlation between exports and innovation of firms. Bilateral trade, therefore, provides an essential channel for the spillover of knowledge. (Zhu \& Jeon, 2007). Testing these spillover and learning effects is an appropriate method to target the impact of exports on innovation. (Salomon \& Shaver, 2005).

The purpose of this study was to investigate the relationship between exports and innovation and focus on the role of the heterogeneity in exports using detailed industry-level cross-sectional data from Malaysia's manufacturing sector in 2014. Notably, the exports were broken down into four programs, namely; the number of export destinations, the volume of exports, the volume of exports to low-income countries and the volume of exports to highincome countries. The model adopted in this study was based on the CDM model, introduced by Crepon, Duguet \& Mairesse (1998). The CDM model includes three components. First, firms in industries decide whether to engage in innovation activities. Second, if these firms in industries decide to carry out innovation activities, the next step is to focus on the level of innovation intensity of the industry. Third, for those industries which engage in innovation activities, knowledge or innovation production functions are shown in this model.

Moreover, Lee (2008), showed that taking part in the export market can prompt enterprise learning and, thus, improve the performance of innovation in firms. Therefore, firms can enter new geographic markets offering new and improved products by undertaking innovation activities to enhance their success in exporting their goods and services, while at the same time expanding their share of their domestic market. The possible positive correlation between exports and innovation has become a topic of interest to many scholars, most especially the effect of exports on innovation.

The outline for the rest of this article is as follows. A review of literature related to this study is discussed in Section 2.0. The methodology used in the analysis together with the data are presented in Section 3. This is followed by the empirical results in Section 4. Lastly, Section 5 contains the concluding remark regarding this study together with a discussion of the known limitations of the research and some suggestions for further study.

\section{Background of study}

Malaysia is a developing country which is known for its long-standing commitment to maintaining relatively open regimes for trade and investment policy. Trade is vital, with the export and import of both goods and services equivalent to about $130 \%$ of the nation's GDP. Under a virtual free trade system, a characteristic of the protection system is that the trade policy system is highly decentralised. Reflecting the country's changing financial situation, Malaysia's trade policy has undergone many changes since the nation's independence in 1957. Exports are an important part of international trade. After independence, Malaysia's main exports were rubber and tin, which at that time accounted for $60 \%$ and $12 \%$ of Malaysia's total exports, respectively. After independence, many changes occurred, diversifying the nation's industries in the fields of agriculture and manufacturing. Trade policies were promoted through fiscal incentives, for example, the development of free trade zones and the creation of export processing attracted significant foreign investment. In 1994, manufactured goods accounted for $77.4 \%$ of Malaysia's total exports, whilst in the same year, Malaysia joined the World Trade Organization (WTO). During the period 1997-2003, despite the Asian financial crisis, Malaysia still managed to maintain a trade surplus. Since independence, Malaysia's exports have increased by around $80 \%$, which shows that the country has achieved amazing export growth (Trade Chakra, 2008).

Malaysia's trade policy has focused on further integrating the country with the world economy and enhancing its global position as a trading nation. Malaysia's trade policy has aimed to create a free and fair international trading environment. Although Malaysia continues to attach great importance to the rules-based multilateral trading system under the World Trade Organization (WTO), Malaysia has also sought regional and bilateral trade arrangements to 
complement the multilateral approaches. Trade policy has focused on both internal and external improvements to ensure that the level of exports has continued to grow. Domestically, the policies have aimed to develop high-quality and innovative products and to build brand awareness and consumer recognition. Another major step has been to expand the range of products to reduce excessive reliance on electrical and electronic products. Bilateral trade agreements have been seen as providing a means for faster and higher levels of trade liberalization, which have created appropriate conditions for effective trade entry with trading partners. Many bilateral trade agreements have been limited to goods trade, services trade and investment matters.

To ensure that export growth has remained strong, Malaysia's trade policy has also focused on strengthening its presence in traditional markets and diversifying into non-traditional export markets. Malaysia has actively promoted trade in emerging markets, such as China, India, the Middle East, Africa and new EU member states. The most current focus of Malaysia's trade policy has been on promoting the development of the services and manufacturing sectors for exports. As can be seen from Figure 1.2, since Malaysia's independence, the total value of exports of goods and services has been on the rise, reaching its highest level in 2011, at US\$ 254.02 billion. The value of exports recorded in 2014 was US\$249.468 billion, a small decrease of about US\$5 billion compared with 2011. In terms of geographical grouping, as shown in Figure 1.3, Malaysia's main export destinations in 2014 were the Northeast Asian countries and Southeast Asian countries, which recorded total export values of RM 264.67 billion and RM 213.40 billion, respectively. Among high-income countries, the destination with the greatest value of exports from Malaysia were Northeast Asian countries, followed by the European Union countries with a total of RM 72.84 billion. Among the low-income countries exported to, the destination with the greatest value of exports from Malaysia were the Southeast Asian countries, followed by South Asian countries with a total of RM 42.84 billion. Moreover, Figure 1.4 indicates Malaysia's major trading partners in 2014, as can be seen from the figure, Malaysia's main trading partners were China and Singapore, which accounted for $14.3 \%$ and $13.4 \%$ of Malaysia's total trade, respectively. In terms of regions, Malaysia's main trading partners were Southeast Asian countries (Singapore, Thailand, Indonesia, Vietnam, Philippines, etc.) and East Asian countries (Mainland China, Taiwan, Japan, South Korea, etc.), accounting for $23 \%$ and $32 \%$ of Malaysia's total trade, respectively.

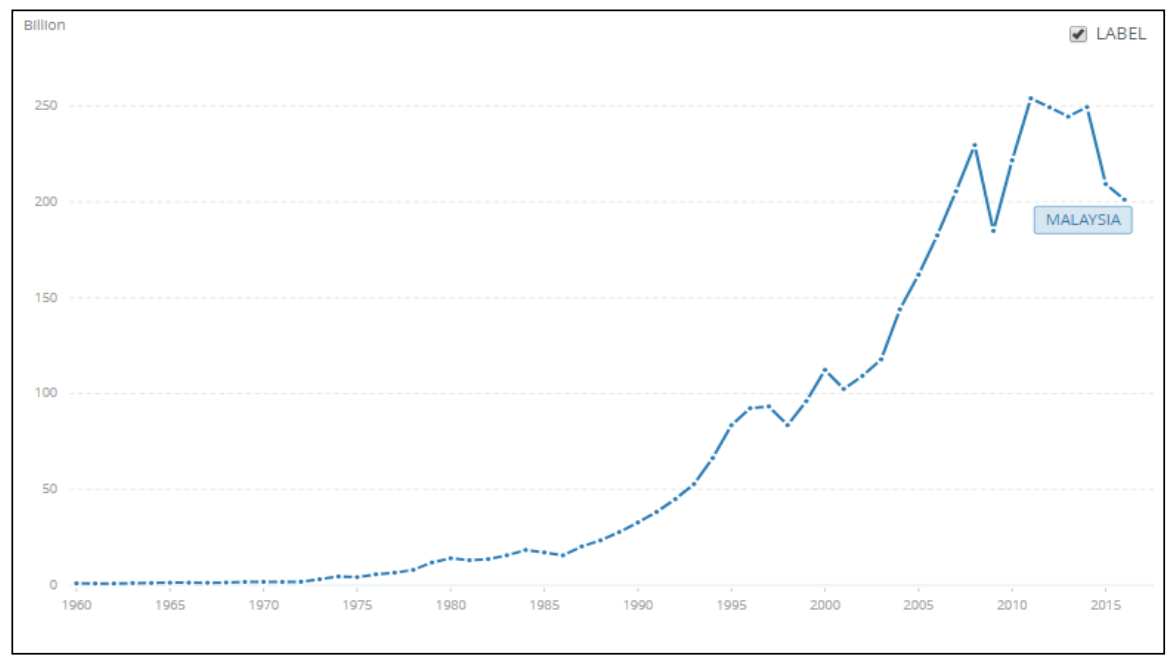

Source: World Bank

Figure 1.2: Exports of Goods and Services (Current US\$)- Malaysia 


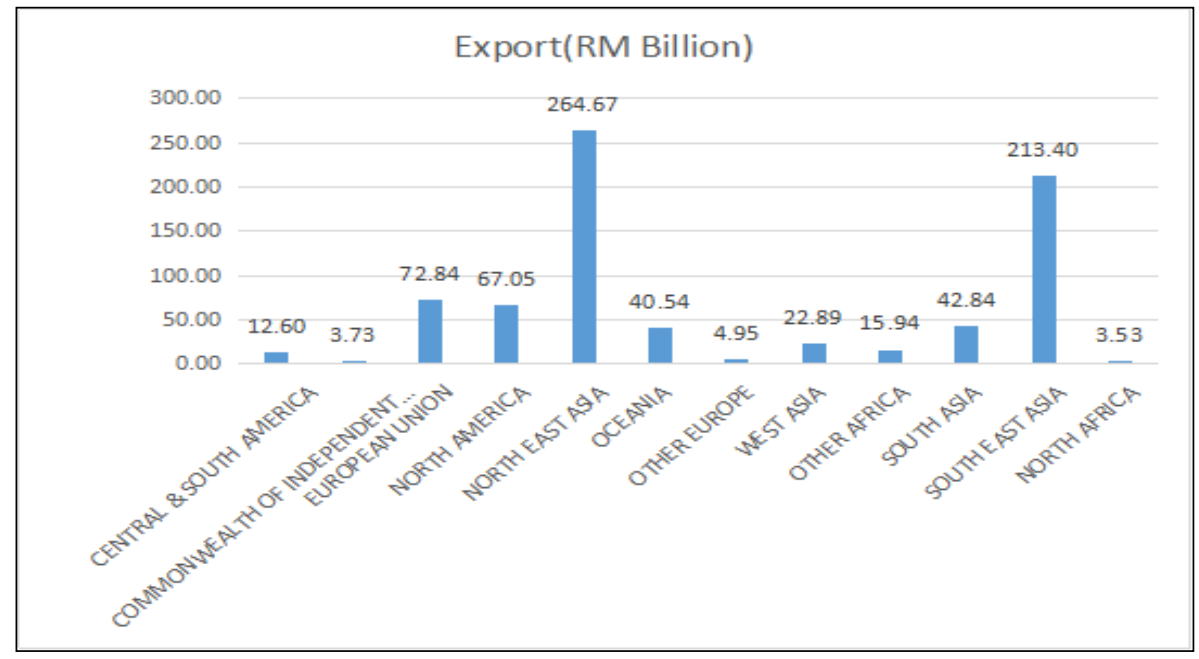

Source: Malaysia External Trade Statistics

Figure 1.3: Malaysia's Exports by Geographical Grouping in 2014

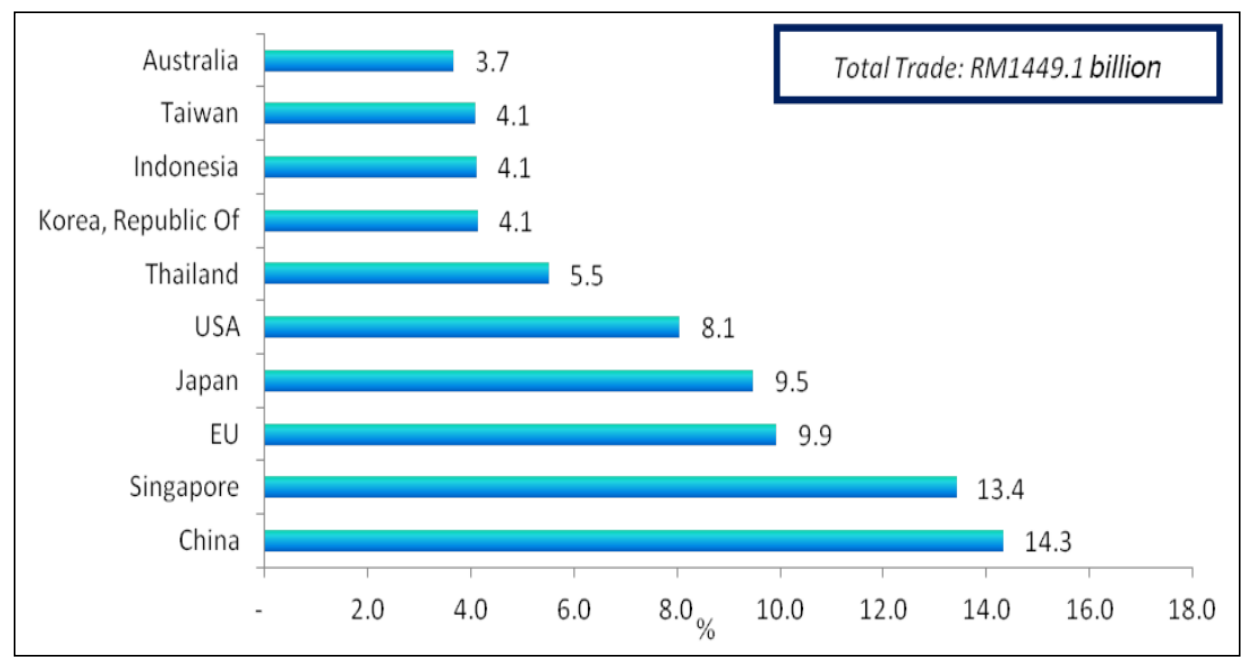

Source: Department of Statistic Malaysia

Figure 1.4: Total Trade by Major Countries in 2014, percentage share

Furthermore, since Malaysia's independence, manufacturing has been the main driver of Malaysia's economic growth. The country has steadily shifted from a resource-based economy to high-tech, knowledge-based and capital-intensive industries, such as medical equipment and green technology. The ETP has identified the manufacturing-related NKEA that need to be developed and supported. It has aimed to establish higher value-added sub-sectors, such as LED lighting, solar panels and generic drug production. During 2014, the external environment continued to be affected by global economic uncertainty, which suppressed the demand for manufactured products. The European sovereign debt crisis, the fiscal cliff in the United States and the stagnation of the Japanese economy affected the export performance of manufactured goods. Despite these challenges, the manufacturing industry continued to grow steadily by $6.1 \%$ in 2014, a substantial increase from the growth rate of $4.4 \%$ in 2012.

The manufacturing industry's contribution to the growth of the GDP in 2014 was $22.9 \%$, making it the second-largest contributor, after the service industry. Figure 1.5 shows the 
share of manufacturing in Malaysia's GDP. As can be seen, manufacturing's share of the GDP was on an upward trend before 2004, reaching its highest point of $31 \%$ in 2000 . After 2004, the share of the GDP has shown a downward trend. However, the share of manufacturing in the GDP has remained at a high level, and as can be seen from the figure, the share is still higher than the average level of high and middle-income countries.

Moreover, Figure 1.6 shows the share of manufacturing exports in Malaysia's total exports. As shown in the figure, the share of manufacturing exports has indicated an upward trend, reaching a maximum of $80 \%$. Currently, the manufacturing sector accounts for about $23 \%$ of the GDP and more than 70\% of Malaysia's total exports. Considering the importance of the manufacturing sector to Malaysia, both scholars and policy-makers have tried to determine the status of innovation in the manufacturing sector, and regard manufacturing as a representative sector in Malaysia.

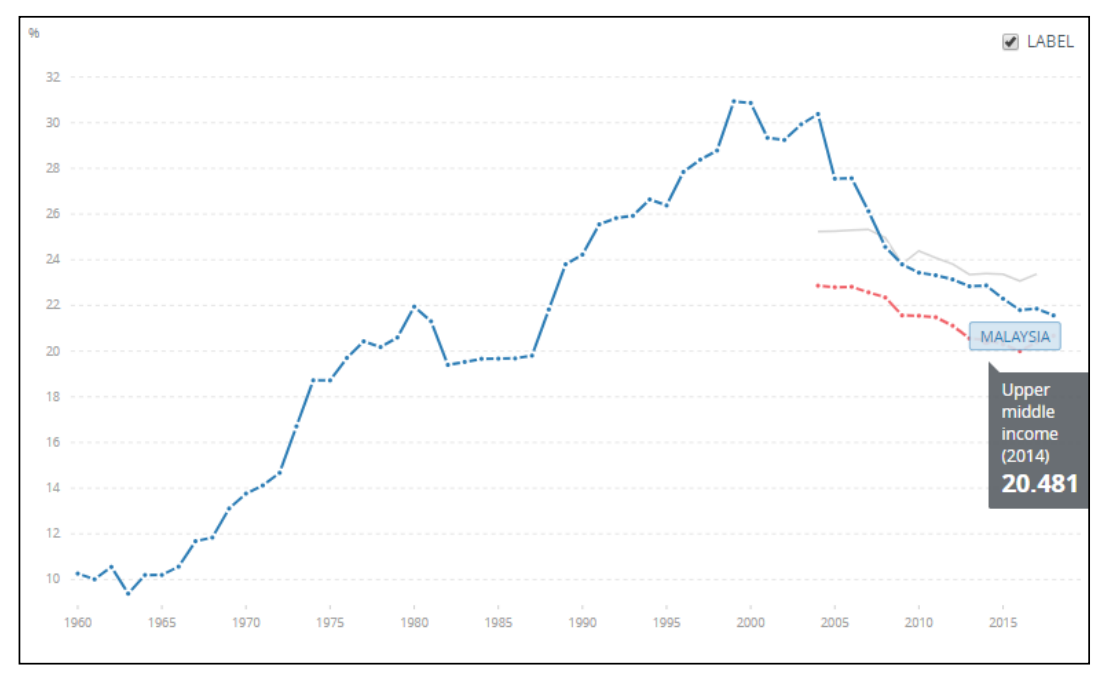

Source: World Bank

Figure 1.5: Manufacturing, value added (\% of the GDP) - Malaysia

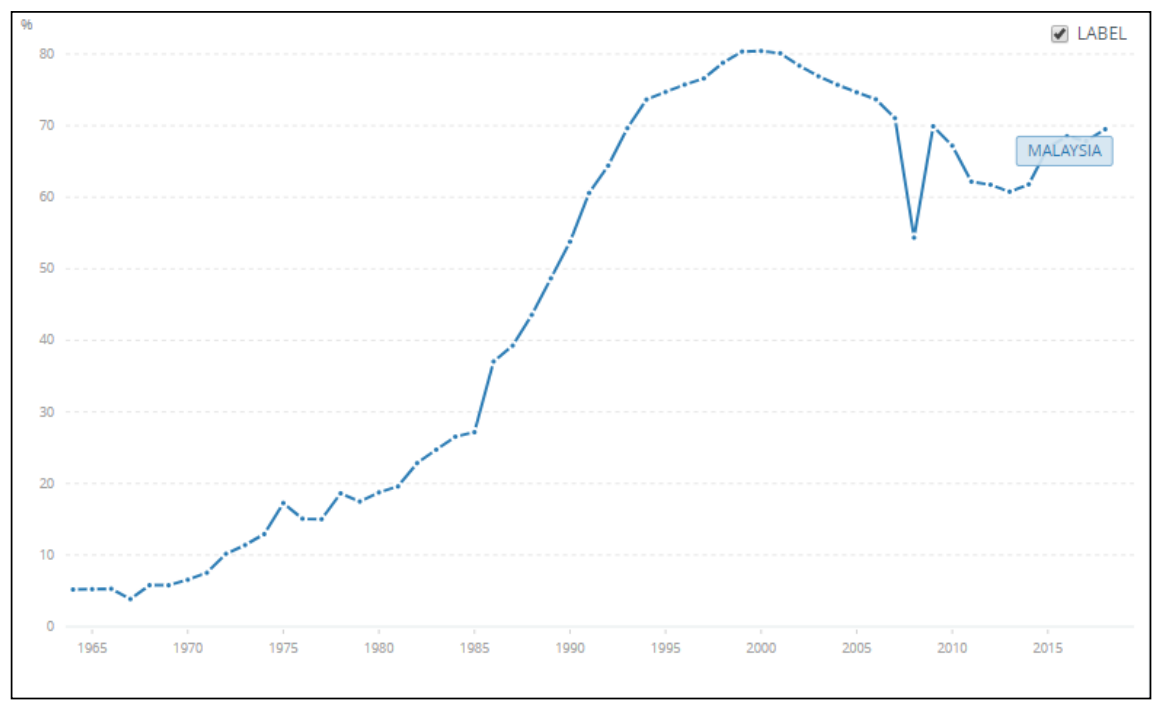

Source: World Bank

Figure 1.6: Manufactures exports (\% of merchandise exports) - Malaysia 


\section{LITERATURE REVIEW}

A significant number of researchers have studied the relationship between exports and innovation over the past decades. To focus on distinct literature related to this topic, the discussion has been confined to three strands of literature. The first strand focuses on the relationship between innovation and exports. The second strand relates to the study of the determinants of innovation. And the third strand concerns the heterogeneity of exports.

\section{Innovation and Exports}

How do exports affect innovation? Firms that enter foreign markets through exporting can acquire a variety of knowledge that is not available from the domestic market. Moreover, they are challenged by new competitors in foreign markets and face various requirements from overseas customers. These stimuli will prompt exporters to engage in innovation activities, such as product and process innovations, and market and organizational innovations. Overall, the relationship between exporting and innovation is achieved mainly through competition, learning and customer feedback.

The body of existing literature linking exports and innovation is enormous. Exporting is the most common way for firms to achieve international expansion. Participation in exportation activities will enable firms to improve their competitive position and productivity, and this process has been described as "learning by exporting". Some scholars have investigated whether total factor productivity will increase after firms become exporters. Besides, many studies have found empirical evidence consistent with the concept of "learning by exporting" (e.g., Ozler \& Yilmaz, 2001; Blalock \& Gertler, 2004; Aw, Chung, \& Roberts, 2000). These authors each believed that to assess whether a firm has learned, a better method would be to study the learning output directly. However, various factors affect the effect of exports on productivity, therefore, it isn't easy to understand the effect of exports on productivity. As a consequence, some studies argued that innovative outcomes of firms could more directly than total factor productivity to measure the phenomenon of "learning by exporting". For instance, Salomon and Shaver (2005) investigated innovative outcomes and argued that which can more directly than productivity to capture the output of "learning by exporting". They showed that after firms engaged in exporting that their patent applications will be increased, and this effect was more significant with further lags. Moreover, the results showed that product innovations increased after exporting commenced and this effect was most notable with two years lags.

Similarly, Salomon (2006) argued that exporters could obtain a variety of knowledge inputs that are not available in the domestic market. This knowledge would flow back to the focus firm and lead to an increase in innovation, which emphasised the potential for learning by exporting. He showed that firms exporting to developed countries would experience increased innovation productivity. Moreover, firms that directly contacted foreign markets, instead of relying on export brokers, may innovate more because they maintained close ties with information channels.

Besides, Lee (2008) summarised the extensive literature related to the innovation and exports of Malaysia. He indicated that variables, such as the size of the firm, the expenditure on $\mathrm{R} \& \mathrm{D}$, and exports ownership of the firm were significantly associated with the propensity to innovate, however, compared with product innovation, these variables have a more significant impact on process innovation. These findings indicated that development and progress in a developing country are driven more by process innovation than product innovation.

\section{Determinants of Innovation}

Altenburg (2006) argued that the strength of Asian development lay less in the strategies that reproduced successful national systems of innovation and more in the capacity for institutional change to open up new development trajectories with greater emphasis on knowledge and learning. Based on a large firm-level data set from innovation surveys of the Czech Statistical 
data over the period 2004-2007, the innovation activities of firms were modelled as a four-stage model (CDM), Zemplinerová \& Hromádková (2012) concluded that innovation input significantly increased innovation output, with increasing firm's size, however, ceteris paribus, the innovation output was decreasing. Hence, suggesting that bigger firms are less efficient in transforming the innovation input into an output. Besides, their analysis also showed that access to subsidies had a significant, yet negative influence on innovation output, hence questioning the efficiency of the supported firms and also having some implications for competition policy. Utilizing data from the National Survey of Innovation with firm-level of Malaysia to investigate the determinants of innovation in the manufacturing sector, Lee (2004), found that, compared with small firms, large firms were more likely to innovate. Besides, private limited and public limited firms were twice as likely to innovate than sole proprietorship firms.

On the other end, Le (2015) argued that although the Malaysian economy had achieved high growth for over five decades, after the Asian financial crisis of 1997, the growth of the Malaysian economy slowed and the downturn remained until the 2008 global financial crisis made matters worse. He argued that the reason for the prolonged downturn was because Malaysia had lost its comparative and competitive advantages in several products to other developing economies that were opening up and joining the trend of export-led growth in addition to losing ground when competing with developed countries with new technologies. Chandran, Rasiah and Wad (2009) investigated the R\&D activities and the internationalization of innovation and technological upgrading activities undertaken by foreign firms within the Malaysian manufacturing sector. Their study concluded that the Malaysian manufacturing system of innovation was weakly positioned but showed limited evidence of process innovation and not product innovation. Although Malaysia had not been chosen as a site for offshoring or outsourcing of R\&D activities to any significant degree by foreign firms, the process innovation conducted by foreign subsidiaries was on the rise. It was also found that technological learning by local firms was mainly through linkages, sub-contracting and technological transfers.

\section{Heterogeneity of Exports}

Yang (2018) utilized comprehensive transaction-level trade data from China Customs to construct various dimensional measures of exports. He concluded that exports overall had a positive impact on promoting innovations in terms of $R \& D$ and new product sales. However, the innovation-enhancing effect of exports depended on the heterogeneity in exports. Firms with a greater variety of exports, increased market diversification, and higher export quality were associated with a higher propensity for $\mathrm{R} \& \mathrm{D}$ and increased new product sales, while process exports were found to have a negative association with innovations. On the other hand, the characteristics of foreign customers were found to be the main source of heterogeneity in exporting, Alcacer \& Oxley (2014). Additionally, Crino and Epifani (2012) divided the firms' export destinations within the data set into high-income and low-income countries, they showed that innovation activities were inversely correlated with the share of exports to low-income destinations. Salomon and Jin (2008), found that exporting was related to the post-incremental increases in innovative productivity for firms in both technologically-leading and technologically-lagging industries. Firms in technologically lagging industries were found to obtain more patents after exporting than technologically leading industries, as firms from lagging industries were "learning by exporting" faster than firms from technologically leading industries.

\section{METHODOLOGY}

The model adopted in this study was based on the CDM model, introduced by Crepon, Duguet and Mairesse (1998), which can study several interrelated issues while controlling simultaneity and causality. It is generally believed that all companies will innovate, regardless of whether they are engaged in export activities or already have introduced some innovations. Hence, the 
whole sample of firms was used in the analysis, not just innovating and exporting firms. Besides, due to the constraints caused by the limitations of data availability, data from the industry-level in the manufacturing sector in Malaysia during 2014 was used.

There are three components in this CDM model. First, firms in industries have to decide whether they wish to carry out innovation activities. Second, if these firms choose to carry out innovation activities, what is the level of innovation intensity that they choose to employ. Third, the knowledge or innovation production function of firms in industries is shown at this stage. Such a model has the merit of reducing endogeneity and simultaneity problems.

\section{Variables}

The dependent variable in the first model was a binary endogenous innovative variable which indicated whether the industry engaged in innovation activities, or not. The explained variable in the second model was the level of innovation intensity of industry which illustrated the percentage of firms in the industry which carried out innovation activities. Lastly, innovation production was the dependent variable in the third model, and it showed the innovation output of the industry after firms in this industry undertook innovation activities, where patent counts measured the level of innovation production. The independent variables included the heterogeneous variables of exports, including, export country (COUNTRY), the volume of exports (VOLUME), the volume of exports to high-income countries (HIGH) and low-income countries (LOW). All of these variables were measured in nature logarithms.

Besides, some control variables were also added to the models. Industry size was controlled for as there was a relationship between the degree of innovation and industry size. The industry size was measured as the natural logarithm of total employees. Besides, exporters tended to be larger than non-exporters, as could be seen in the second line in Table 3.1, the average number of employees' in export industries was 11,863, while in non-export industries it was 8,177 . By omitting this variable, an estimated export effect might have captured a spurious effect based on size. Moreover, the education level of employees' was also an important factor for industry innovation, and the most representative available variable of the employees' education level was employee wages, thus, the per capita salary of the industry were also introduced as an independent variable. Finally, the level of total factor input in an industry may also affect the industry's level of innovation. Therefore, industry input could also be introduced as an explanatory variable. As shown in both the third and fourth lines of Table 1, for exporters, there were also higher per capita salary and higher industry input.

Table 1: Comparing Control Variables between Exporters and Non-exporters Industries

\begin{tabular}{lll}
\hline & Exporter & Non-exporter \\
\hline Average number of employees & 11863 & 8177 \\
Average per capita salary $\left(\mathrm{RM}^{*} 000\right)$ & 30.749 & 27.535 \\
Average value of input $\left(\mathrm{RM}^{* 000)}\right.$ & 5170441.032 & 1899430.907 \\
\hline
\end{tabular}

\section{Model 1: Carrying out innovation activities, or not}

First, firms in industries of manufacturing have to decide whether to carry out innovation activities. The propensity of industry $i$ to engage in innovation-related activities is modelled as:

$$
I_{i}=\beta_{0}+\beta_{1} x_{0 i}+\beta_{3} x_{1 i}+e_{0 i}=X_{i}^{\prime} \beta+e_{0 i}
$$

Where $I_{i}$ is a binary endogenous innovative variable, when the firms in this industry carry out innovation activities, its value is one, otherwise, it is zero. That is: 


$$
I_{i}=\left\{\begin{array}{lr}
1, & \text { Industryengageininnovation } \\
0, & \text { Industrynotengageininnovation }
\end{array}\right.
$$

$x_{o i}$ and $x_{1 i}$ are the explanatory variables, where $x_{o i}$ represents the export heterogeneity variables and the $x_{1 i}$ represents the control variables. According to the National Survey of Innovation (2015) and data regarding exports from the Department of Statistics Malaysia, the control variables in the industry are in the year of 2014, including industry size (SIZE) (measured as the natural logarithm of total employees), annual per capita salary in the industry (SALARY) and the total input of industry (INPUT). Moreover, the variables of export heterogeneity in the industry that measured by the number of export countries (COUNTRY), and the export volume (VOLUME) that has been divided into the total volume exports to lowincome countries (LOW) and high-income countries (HIGH). $\beta_{0 i}$ and $\beta_{1 i}$ are the coefficient vector of independent variables and $e_{0 i}$ are the error terms.

The dataset contained information on the exports of the firms in industry in the year 2014 to the following destinations; Central \& South America, North Africa, the Commonwealth of Independent States, the European Union, North East Asia, Oceania, Other Africa, South East Asia, North America, Other Europe, West Asia, South Asia. These destinations were aggregated into two groups, namely; high-income and low-income destinations. The former group included; North America, Central \& South America, the European Union, Oceania, Other Europe, North East Asia, West Asia and the Commonwealth of Independent States. Whereas, the latter included; North Africa, Other Africa, South East Asia and South Asia.

Equation (1) was conducted by using the Probit estimator in the STATA software application, as the dependent variable was binary. After the regression was complete, the Pearson test was utilised to test for the goodness-of-fit of the model.

\section{Model 2: The innovation intensity of the industry}

Second, if firms in the industry decide to carry out innovation activities, then the innovation intensity of the industries was focused on. Here, only those industries to undertake innovation activities were considered. The level of innovation intensity was measured by the percentage of firms in the industry that were involved in innovation activities in the manufacturing sector in Malaysia. The level of innovation intensity of industry $i$ was modelled as:

$$
\operatorname{In}_{i}=\alpha_{0}+\alpha_{1 i} x_{2 i}+\alpha_{2 i} x_{3 i}+e_{1 i}
$$

Where $I n_{i}$ was the variable of innovation intensity, which was measured by the proportion of firms in the industry involved in innovation activities, $x_{2 i}$ and $x_{3 i}$ were the explanatory variables, where $x_{2 i}$ represented the export heterogeneity variables and the $x_{3 i}$ represented the control variables. $\alpha_{1 t}$ and $\alpha_{2 t}$ were the coefficient vectors and $e_{1 i}$ were the error terms. Following Crepon, Duguet and Mairesse (1998), it was assumed that $x_{0 i}=x_{2 i}, x_{1 i}=$ $x_{3 i}$, which meant the set of independent variables for the propensity to carry out innovation activities was the same as the level of innovation intensity.

Equation (3) was estimated as a Generalized Method of Moments (GMM) model in the STATA software application. As there was concern that positive shocks to innovation would be correlated with other exogenous factors (for example, existing research has shown that innovation was related to the expenditure of $R \& D$ ), it was expected that the focal explanatory variable was predetermined and not strictly exogenous. Hence, to estimate the impact of export heterogeneity on innovation the linear GMM method was adopted.

\section{Model 3: Innovation production functions}

According to previous research and the National Survey of Innovation (NSI), intellectual property is the most crucial measurement of innovation (Scherer, 1965; Basberg, 1982, 1987; 
Comanor \& Scherer, 1969; Hall et al., 2001; Henderson and Cockburn, 1994, 1996). Intellectual property can be measured by the number of applied and granted patents and applied and registered industrial designs, trademarks, geographical indications, utility innovations and copyrights. Therefore, the number of applications of intellectual property has been considered in this paper. Moreover, patent data and patent counting have been widely used in industrial economics research regarding technology and innovation, Hall et al. (2001). Therefore, the innovation production function can be modelled as follows:

$$
F_{i}=\gamma_{0}+\gamma_{1 i} x_{4 i}+\gamma_{2 i} x_{5 i}+e_{2 i}
$$

Where, $F_{i}$ represents the patent counts in industry i, ${ }^{x_{4 i}}$ and ${ }^{x_{5 i}}$ are the explanatory variables, which represent the export heterogeneity variables and control variables, respectively. Here, it is also assumed that $x_{0 i}=x_{4 i}$ and $x_{1 i}=x_{5 i}$, which means that the set of explanatory variables for the innovation intensity are the same as the innovation production. $\gamma_{1 i}$ and $\gamma^{2 i}$ are the coefficient vectors and $e_{2 i}$ are the error terms. Equation (4) was estimated through the Negative Binomial Regression model by maximum likelihood in the STATA software application.

\section{Data}

The data used in this study included innovation-related data, export heterogeneity-related data, and the data concerning industry size, per capita salaries and inputs in industry.

\section{Data about Innovation}

The cross-sectional data of the innovation in the manufacturing sector in Malaysia comes from the National Survey of Innovation 2015 (NSI) conducted by the Malaysian Science and Technology Information Center (MASTIC) of the Ministry of Science, Technology and Innovation, which covered the period of 2012-2014. The focus was on the manufacturing sector in Malaysia. Table 2 shows the division of innovative and non-innovative firms in the manufacturing sector in Malaysia. As can be seen from the table below, about two-thirds of the companies in the manufacturing sector engaged in innovation, which indicates that innovation activities are popular in Malaysia's manufacturing sector. Therefore, justifying the decision to choose the manufacturing sector as the research target.

Table 2: Innovative and Non-innovative Firms in Manufacturing

\begin{tabular}{lll}
\hline sector & Manufacturing & $\%$ \\
\hline Innovative & 469 & 68.87 \\
Non-Innovative & 212 & 31.13 \\
Total & 681 & 100 \\
\hline
\end{tabular}

Source: National Survey of Innovation 2015

Based on the data from the NSI, the industry classification activities in the manufacturing sector according to the Malaysia Standard Industrial Classification (MSIC) 2008 classifications were utilized. According to the MSIC, the manufacturing sector in Malaysia can be divided into a total of 200 categories, among them, 171 categories carry out innovation activities. As highlighted in Table 3, the Innovation variable is a binary variable, which indicates whether industry engages in innovation, or not, where zero represents where industry did not engage in innovation activities, and one represents otherwise. The second row in Table 
3.2 shows the descriptive statistics of the innovation intensity of the industry, which was measured as the percentage of firms carrying out innovation activities in the industry.

Data concerning patent counts came from the World Bank World Development Indicators Online Database and the NSI. Here the focus has been on industries that engaged in innovation. The statistics regarding this are described in the third row of Table 3.

Table 3: Descriptive Statistics of Innovation and Innovation Intensity

\begin{tabular}{llllll}
\hline Variable & Obs & Mean & Std.Dev. & Min & Max \\
\hline Innovation & 200 & .545 & .499 & 0 & 1 \\
Intensity & 171 & .583 & 1.139 & .001 & 8.563 \\
Patent counts & 171 & 11.053 & 21.706 & 0 & 163 \\
\multicolumn{5}{l}{ Source: National Survey of Innovation 2015 \& World Bank World Development Indicators Online Database }
\end{tabular}

Data about size, salary, input and the heterogeneity of export

Data regarding the industry size, salaries and input concern the year 2014, which came from the Report on Survey of Manufacturing Industries 2015 which was conducted by the Department of Statistics Malaysia. This study presents the statistics of the manufacturing sector based on the data collected from the Annual Manufacturing Industries Survey for the year of 2014. The manufacturing sector covers Section $\mathrm{C}$ under Malaysia Standard Industrial Classification (MSIC) 2008 Ver. 1.0, which is in line with the International Standard Industrial Classification of All Economic Activities (ISIC) Revision 4. The statistics of these variables are described in Table 4.

Table 4: Descriptive Statistics of Input, Industry size, Salary

\begin{tabular}{llllll}
\hline Variable & Obs & Mean & Std.Dev. & Min & Max \\
\hline Employment & 200 & 10480.99 & 16986.51 & 29 & 106000 \\
Salary $\left(\mathrm{RM}^{* 000)}\right.$ & 200 & 29.543 & 11.301 & 8.931 & 88.529 \\
Input $\left(\mathrm{RM}^{*} 000\right)$ & 200 & 3940000 & $1.26 \mathrm{e}+07$ & 528 & $1.22 \mathrm{e}+08$
\end{tabular}

Source: Report on a survey of manufacturing industries 2015

Besides, the statistics of the heterogeneity of export in 2014 are shown in Table 5, including the number of export countries, the volume of exports of industry, the volume of exports to high-income countries and exports to low-income countries, which was obtained from the Malaysia External Trade Statistics conducted by Department of Statistics Malaysia.

Table 5: Descriptive Statistics of the Heterogeneity of Export

\begin{tabular}{llllll}
\hline Variable & Obs & Mean & Std.Dev. & Min & Max \\
\hline Export Countries & 200 & 70.06 & 87.285 & 0 & 580 \\
Export Volume $\left(\mathrm{RM}^{*} 000\right)$ & 200 & 2380000 & 6480000 & 0 & $6.04 \mathrm{e}+07$ \\
Low-income Countries $\left(\mathrm{RM}^{*} 000\right)$ & 200 & 997000 & 3920000 & 0 & $4.88 \mathrm{e}+07$ \\
High-income Countries $\left(\mathrm{RM}^{*} 000\right)$ & 200 & 1380000 & 3400000 & 0 & $2.18 \mathrm{e}+07$ \\
\hline
\end{tabular}

Source: Malaysia External Trade Statistics

\section{EMPIRICAL RESULTS}

\section{Model 1: Engaged in innovation activities or not}

From the results presented in Table 6, the results obtained from the Probit model indicated that all of the variables, except the volume of exports to high-income countries (Log_high), were statistically significant and positively correlated with innovation. 
Table 6: Engaged in Innovation Results: Probit Regression

Dependent Variable: Innovation

\begin{tabular}{|c|c|c|c|c|}
\hline $\begin{array}{l}\text { Independent } \\
\text { Variable }\end{array}$ & (1) & (2) & (3) & (4) \\
\hline Log_country & $\begin{array}{l}0.088 * * \\
{[1.96]}\end{array}$ & & & \\
\hline Log_volume & & $\begin{array}{l}0.025 * \\
{[1.65]}\end{array}$ & & \\
\hline Log_low & & & $\begin{array}{l}0.027 * \\
{[1.73]}\end{array}$ & \\
\hline Log_high & & & & $\begin{array}{l}0.025 \\
{[1.60]}\end{array}$ \\
\hline Log_size & $\begin{array}{l}0.412 * * * \\
{[5.99]}\end{array}$ & $\begin{array}{l}0.414 * * * \\
{[6.03]}\end{array}$ & $\begin{array}{l}0.414 * * * \\
{[6.03]}\end{array}$ & $\begin{array}{l}0.414 * * * \\
{[6.03]}\end{array}$ \\
\hline Log_salary & $\begin{array}{l}0.113 \\
{[0.38]}\end{array}$ & $\begin{array}{l}0.117 \\
{[0.40]}\end{array}$ & $\begin{array}{l}0.105 \\
{[0.36]}\end{array}$ & $\begin{array}{l}0.124 \\
{[0.42]}\end{array}$ \\
\hline cons & $\begin{array}{l}-3.689 * * * \\
{[-3.53]}\end{array}$ & $\begin{array}{l}-3.687 * * * \\
{[-3.52]}\end{array}$ & $\begin{array}{l}-3.656 * * * \\
{[-3.49]}\end{array}$ & $\begin{array}{l}-3.703 * * * \\
{[-3.54]}\end{array}$ \\
\hline $\mathrm{N}$ & 200 & 200 & 200 & 200 \\
\hline $\begin{array}{l}\text { Pearson } \\
\text { chi2(196) }\end{array}$ & 200.91 & 202.42 & 202.51 & 202.29 \\
\hline Prob > chi 2 & 0.3899 & 0.3615 & 0.3598 & 0.3639 \\
\hline
\end{tabular}

Notes: $\mathrm{Z}$ statistics are in brackets.

$* \mathrm{p}<0.1, * * \mathrm{p}<0.05, * * * \mathrm{p}<0.01$

However, given the nature of the probit model, the coefficients obtained in Table 6 were not marginal effects. The calculated marginal effects are shown in Table 7. As presented in Table 7, a 1 per cent increase in the number of countries that an industry is exporting to, tended to increase the industry's level of innovation by 0.026 per cent. Additionally, a 1 per cent increase in the total volume of exports $\left(\mathrm{RM}^{*} 000\right)$ tended to lead to increasing the industry's level of innovation by 0.008 per cent and, interestingly, a 1 per cent increase (decrease) in the total volume of exports to low-income countries $\left(\mathrm{RM}^{*} 000\right)$ also tended to increase the industry's level of innovation by 0.027 per cent. Lastly, the volume of exports to high-income countries (Log_high) had no significant impact on the level of innovation in the manufacturing sector. On the other hand, industry size was statistically significant in all of the four regressions and was positively related to the dependent variable (Innovation). However, although the coefficient of the industry per capita salary was positive in magnitude in all of the four regressions, it was not statistically different from $0(\mathrm{p}>0.1)$.

Table 7: Marginal Effects of Engagement in Innovation: Probit Regression

\begin{tabular}{lllllllll}
\hline $\begin{array}{l}\text { Dependent Variable: Independent } \\
\text { Patent Counts }\end{array}$ & dy/dx & $\begin{array}{l}\text { Delta_method } \\
\text { Std.Err. }\end{array}$ & $\mathrm{Z}$ & $\mathrm{P}>|\mathrm{Z}|$ & \multicolumn{2}{l}{$\begin{array}{l}\text { [95\% Conf. } \\
\text { Interval] }\end{array}$} \\
\hline \multirow{3}{*}{$(1)$} & Log_country & 0.026 & 0.013 & 2.01 & 0.04 & 0.001 & 0.052 \\
& Log_size & 0.124 & 0.015 & 8.33 & 0.00 & 0.095 & 0.153 \\
& Log_salary & 0.034 & 0.088 & 0.38 & 0.70 & -0.139 & 0.207 \\
\hline & Log_volume & 0.008 & 0.005 & 1.71 & 0.087 & -0.001 & 0.017 \\
& Log_size & 0.414 & 0.069 & 6.03 & 0.00 & 0.280 & 0.549 \\
& Log_salary & 0.117 & 0.295 & 0.40 & 0.692 & -0.461 & 0.694 \\
\hline
\end{tabular}


Exports and Innovation in Malaysia: the Role of Heterogeneity

\begin{tabular}{llllllll}
\hline & Log_size & 0.414 & 0.069 & 6.03 & 0.00 & 0.279 & 0.548 \\
& Log_salary & 0.105 & 0.296 & 0.36 & 0.722 & -0.474 & 0.685 \\
\hline \multirow{4}{*}{$4)$} & Log_high & 0.008 & 0.005 & 1.63 & 0.102 & -0.002 & 0.017 \\
& Log_size & 0.125 & 0.015 & 0.42 & 0.00 & 0.096 & 0.155 \\
& Log_salary & 0.038 & 0.089 & 0.42 & 0.672 & -0.137 & 0.212 \\
\hline
\end{tabular}

Model 2: The innovation intensity of industry

Table 8 highlights the empirical result of the impact of export heterogeneity on innovation intensity. As indicated in Table 8, a 1 per cent increase in the number of countries that an industry exported to tended to lead to a 0.068 per cent increase in the level of innovation intensity of the industry. Besides, a 1 per cent increase in the total volume of exports (RM*000) was associated with a 0.018 per cent increase in the level of innovation intensity and for every 1 per cent increase in the total volume of exports to low-income countries $\left(\mathrm{RM}^{*} 000\right)$ in the manufacturing sector, the level of innovation intensity in industry would increase (decrease) by 0.02 per cent. In contrast, the volume of exports to high-income countries (Log_high) was found to have no significant impact on the level of innovation intensity of the manufacturing sector in Malaysia. Lastly, larger firms promoted the level of innovation intensity of the industry, whereas, salary did not matter.

Table 8: Innovation Intensity Results: GMM Estimator

Dependent variable: Innovation Intensity

\begin{tabular}{lllll}
\hline $\begin{array}{l}\text { Independent } \\
\text { Variable }\end{array}$ & $(1)$ & $(2)$ & $(3)$ & $(4)$ \\
\hline Log_country & $0.068^{*}$ & & & \\
& {$[1.77]$} & & & \\
Log_volume & & $0.018^{*}$ & & \\
& & {$[1.67]$} & & \\
Log_low & & & $0.020^{*}$ & \\
& & & {$[1.75]$} & 0.019 \\
Log_high & & & & {$[1.62]$} \\
& & & & $0.207 * * *$ \\
Log_size & $0.204^{* * *}$ & $0.207^{* * *}$ & $0.207^{* * *}$ & {$[5.28]$} \\
& {$[5.28]$} & {$[5.27]$} & {$[5.26]$} & -0.208 \\
Log_salary & -0.225 & -0.211 & -0.218 & {$[-0.74]$} \\
& {$[-0.78]$} & {$[-0.75]$} & {$[-0.78]$} & -0.600 \\
cons & -0.556 & -0.598 & -0.579 & {$[-0.79]$} \\
& {$[-0.72]$} & {$[-0.79]$} & {$[-0.77]$} & 171 \\
N & 171 & 171 & 171 & 0.000 \\
P-value & 0.000 & 0.000 & 0.000 & \\
\hline
\end{tabular}

Notes: $\mathrm{Z}$ statistics are in brackets.

$* \mathrm{p}<0.1, * * \mathrm{p}<0.05, * * * \mathrm{p}<0.01$

\section{Model 3: Innovation Production Function}

The dependent variable utilized in Model 3 was; Patent Counts and it was derived through the Poisson Regression model. The assumption of the Poisson Regression was $E\left(Y_{i} \mid x_{i}\right)=\operatorname{Var}\left(Y_{i} \mid x_{i}\right)=\lambda_{i}$, however, if the expectation and variance of $Y_{i}$ were significantly different from each other, then the assumption would no longer hold, thus, the Negative Binomial Regression would be applied. As indicated in Table 9, the Pearson test showed that 
the goodness-of-fit of the four models were significant ( $p$-value $=0$ ), thus, suggesting that the expectation and variance of the Patent Counts were very different. Therefore, it was necessary to introduce the Negative Binomial Regression. The results of the Negative Binomial Regression are shown in Table 10. As indicated in Table 10, the p-values of the Likelihood-ratio test of alpha $=0$ were equal to zero, which indicated that the variance was significantly greater than the expectation. Therefore, the negative binomial regression method was suitable.

Table 9: Innovation Production Results: Poisson Regression

Dependent Variable: Patent Counts

\begin{tabular}{lllll}
\hline $\begin{array}{l}\text { Independent } \\
\text { Variable }\end{array}$ & $(1)$ & $(2)$ & $(3)$ & $(4)$ \\
\hline Log_country & $0.117^{* * *}$ & & & \\
& {$[10.06]$} & & & \\
Log_volume & & $0.032^{* * *}$ & & \\
& & & & \\
Log_low & & & $0.036^{* * *}$ & \\
& & {$[8.90]$} & \\
Log_high & & & $0.033^{* * *}$ \\
& & & & {$[8.33]$} \\
Log_size & $0.411^{* * *}$ & $0.416^{* * *}$ & $0.414^{* * * *}$ & $0.415^{* * *}$ \\
& {$[23.79]$} & {$[24.00]$} & {$[23.95]$} & {$[23.89]$} \\
Log_salary & $-0.260^{* * *}$ & $-0.250^{* * *}$ & $-0.264^{* * *}$ & $-0.240^{* * *}$ \\
& {$[-3.09]$} & {$[-2.98]$} & {$[-3.13]$} & {$[-2.86]$} \\
cons & $-0.729^{* *}$ & $-0.741^{* * *}$ & $-0.703^{* * *}$ & $-0.748^{* * *}$ \\
& {$[-2.28]$} & {$[-2.33]$} & {$[-2.20]$} & {$[-2.35]$} \\
\hline $\mathrm{N}$ & 171 & 171 & 171 & 171 \\
Pearson goodness- & 5843.391 & 6015.68 & 5987.207 & 6008.494 \\
of-fit & & & & \\
Prob > chi2(167) & 0.000 & 0.000 & 0.000 & 0.000 \\
\hline
\end{tabular}

Notes: $\mathrm{Z}$ statistics are in brackets.

$* \mathrm{p}<0.1, * * \mathrm{p}<0.05, * * * \mathrm{p}<0.01$

Table 10: Innovation Production Results: Negative Binomial Regression

Dependent Variable: Patent Counts

\begin{tabular}{lllll}
\hline $\begin{array}{l}\text { Independent } \\
\text { Variable }\end{array}$ & $(1)$ & $(2)$ & $(3)$ & $(4)$ \\
\hline Log_country & $0.159^{* * *}$ & & & \\
& {$[3.38]$} & & & \\
Log_volume & & $0.051^{* * *}$ & & \\
& & {$[3.22]$} & & \\
Log_low & & & $0.056^{* * *}$ & \\
& & {$[3.32]$} & $0.053^{* * *}$ \\
Log_high & & & {$[3.16]$} \\
& & & & $0.638^{* * *}$ \\
Log_size & $0.634^{* * *}$ & $0.640^{* * *}$ & $0.641^{* * *}$ & {$[7.94]$} \\
& {$[7.94]$} & {$[7.96]$} & {$[7.97]$} & 0.271
\end{tabular}




\begin{tabular}{lllll} 
& {$[0.91]$} & {$[0.73]$} & {$[0.67]$} & {$[0.81]$} \\
cons & $-4.711^{* * *}$ & $-4.574^{* * *}$ & $-4.526^{* * *}$ & $-4.627^{* * *}$ \\
& {$[-3.56]$} & {$[-3.43]$} & {$[-3.39]$} & {$[-3.48]$} \\
\hline lnalpha & $0.488^{* * *}$ & $0.496^{* * *}$ & $0.492^{* * * *}$ & $0.497^{* * * *}$ \\
& {$[4.14]$} & {$[4.21]$} & {$[4.17]$} & {$[4.22]$} \\
alpha & 1.630 & 1.642 & 1.636 & 1.644 \\
$\mathrm{~N}$ & 171 & 171 & 171 & 171 \\
LR test of & & & & 2532.94 \\
alpha=0:chibar2( & 2498.91 & 2529.67 & 2522.33 & \\
01) & & & & 0.000 \\
Prob 2 chibar2 & 0.000 & 0.000 & 0.000 & \\
\hline
\end{tabular}

Notes: $\mathrm{Z}$ statistics are in brackets.

$* \mathrm{p}<0.1, * * \mathrm{p}<0.05, * * * \mathrm{p}<0.01$

Due to the nature of the negative binomial regression model, the coefficients obtained in Table 10 were not the marginal effects. Hence, the findings of Model 3 were based on the calculated marginal effects presented in Table 11. As indicated in Table 11, a 1 per cent increase (decrease) in the number of countries which an industry was exporting to, tended to lead to a 0.021 per cent in the patent counts by that industry. Hence, confirming the important role of the number of countries that the industry is exporting to on the average number of patent counts by the manufacturing sector of Malaysia Additionally, a 1 per cent increase in the total volume of exports $\left(\mathrm{RM}^{*} 000\right)$ tends to increase (decrease) the average number of patent counts by 0.007 per cent, whereas, a 1 per cent increase in the total volume of exports to low-income countries in the manufacturing sector will increase the average number of patent counts by 0.007 per cent. Coincidently, a 1 per cent increase in the total volume of exports to high-income countries in the manufacturing sector is found to increase the average number of patent counts by 0.007 per cent as well. Lastly, on average, a 1 per cent increase in the total employees in the manufacturing sector will increase the average number of patent counts by 0.084 per cent. Hence suggesting that size of the industry does matters.

In addition to Table 10, the Incidence Rate Ratio (IRR) was also included to examine the variation of the average number of patent counts in response to the fluctuation of independent variables by one unit. From the results of the IRR in Table 11, a 1 per cent increase in the number of countries that the industry was exporting to tended to increase the average number of patent counts by 0.012 times. Second, a 1 per cent increase in the total volume of exports in the manufacturing sector would increase the average number of patent counts by 0.011 times. Third, a 1 per cent increase in the total volume of exports to high-income countries and low-income countries in the manufacturing sector tended to increase the average number of patent counts by 0.011 times. Lastly, a 1 per cent increase in the total number of employees in the manufacturing sector would increase the average number of patent counts by 0.019 times.

Table 10: Marginal Effects of Innovation Production: Negative Binomial Regression

\begin{tabular}{llllllll}
\hline $\begin{array}{l}\text { Dependent Variable } \\
\text { Patent Counts }\end{array}$ & Independent & $\mathrm{dy} / \mathrm{dx}$ & $\begin{array}{l}\text { Delta_method } \\
\text { Std.Err. }\end{array}$ & $\mathrm{Z}$ & $\mathrm{P}>|\mathrm{Z}|$ & \multicolumn{2}{l}{ [95\% Conf. } \\
Interval]
\end{tabular}




\begin{tabular}{llllllll}
\hline & & & & \\
(3) & Log_low & 0.740 & 0.279 & 2.65 & 0.008 & 0.192 & 1.288 \\
& Log_size & 8.452 & 2.109 & 4.01 & 0.000 & 4.318 & 12.586 \\
& Log_salary & 2.954 & 4.468 & 0.66 & 0.508 & -5.803 & 11.711 \\
\hline \multirow{3}{*}{$(4)$} & Log_high & 0.697 & 0.273 & 2.55 & 0.011 & 0.161 & 1.233 \\
& Log_size & 8.424 & 2.108 & 4.00 & 0.000 & 4.293 & 12.555 \\
& Log_salary & 3.573 & 4.441 & 0.80 & 0.421 & -5.131 & 12.276 \\
\hline
\end{tabular}

Table 11: The Results of the IRR: Negative Binomial Regression

\begin{tabular}{llllllll}
\hline $\begin{array}{l}\text { Dependent Variable: Independent } \\
\text { Patent Counts }\end{array}$ & \multirow{2}{*}{ IRR } & $\begin{array}{l}\text { Delta_method } \\
\text { Variable }\end{array}$ & \multirow{2}{*}{$\mathrm{Z}$} & \multicolumn{2}{c}{$\mathrm{P}>|\mathrm{Z}| \begin{array}{l}\text { [95\% Conf. } \\
\text { Interval] }\end{array}$} \\
\hline \multirow{4}{*}{$(1)$} & Log_country & 1.172 & 0.055 & 3.38 & 0.001 & 1.069 & 1.285 \\
& Log_size & 1.886 & 0.151 & 7.94 & 0.000 & 1.612 & 2.205 \\
& Log_salary & 1.349 & 0.443 & 0.91 & 0.362 & 0.709 & 2.568 \\
& _cons & 0.009 & 0.012 & -3.56 & 0.000 & 0.001 & 0.120 \\
\hline \multirow{4}{*}{ (2) } & Log_volume & 1.051 & 0.017 & 3.22 & 0.001 & 1.020 & 1.086 \\
& Log_size & 1.896 & 0.153 & 7.96 & 0.000 & 1.620 & 2.220 \\
& Log_salary & 1.279 & 0.429 & 0.73 & 0.464 & 0.662 & 2.468 \\
& _cons & -4.574 & 1.334 & -3.43 & 0.001 & -7.188 & -1.959 \\
\hline \multirow{4}{*}{ (3) } & Log_low & 1.058 & 0.018 & 3.32 & 0.001 & 1.023 & 1.093 \\
& Log_size & 1.899 & 0.153 & 7.97 & 0.000 & 1.622 & 2.233 \\
& Log_salary & 1.251 & 0.421 & 0.67 & 0.505 & 0.647 & 2.420 \\
& _cons & -4.526 & 1.334 & -3.39 & 0.001 & -7.141 & -1.911 \\
\hline \multirow{4}{*}{ (4) } & Log_high & 1.054 & 0.018 & 3.16 & 0.002 & 1.020 & 1.089 \\
& Log_size & 1.893 & 1.152 & 7.94 & 0.000 & 1.618 & 2.216 \\
& Log_salary & 1.311 & 0.436 & 0.81 & 0.416 & 0.683 & 2.516 \\
& _cons & -4.627 & 1.330 & -3.48 & 0.001 & -7.234 & -2.020 \\
\hline
\end{tabular}

\section{CONCLUSION}

Innovation increases the likelihood of business success, and an innovative country will increase its productivity and performance. Malaysia has been an innovation achiever over the past two decades, especially in the fields of innovative exports and commercialization. (Rajah \& Yap, 2015). Moreover, in this era of rapid globalisation, innovation is a crucial factor in maintaining Malaysia's competitiveness in the world. Utilising the CDM model, introduced by Crepon, Duguet \& Mairesse (1998), together with industry-level cross-sectional data from Malaysia, this study investigated the impact of the heterogeneity in exports on the level of innovation in Malaysia.

Overall, the empirical findings of this study indicated that exports were a significant determinant of innovation activities in Malaysia. More specifically, the heterogeneity in exports did matter to industries' innovative activity in Malaysia's manufacturing sector. Exporting to more destinations, exporting greater volumes of product, and exporting to low-income countries had a significant influence on inducing industries to carry out innovation activities and promoted an increased number of patent applications.

Besides, compared to smaller firms, larger firms had a stronger ability to innovate. Therefore, policymakers should encourage larger-sized firms to enhance and escalate their 
innovation activities within their domestic base in Malaysia. Whereas, for the small and medium size of firms, policymakers should look into industrial policies which are aimed at encouraging companies to invest in innovation through strategies, such as subsidies or tax incentive schemes. Secondly, as exports were found to have a positive impact on innovation, policymakers should also incentivise firms to engage in export activities. Programs, such as export grants and technology assistance to improve industries' export capabilities should be considered by policymakers. Additionally, policymakers should also encourage industrial firms to enhance patent applications, as this could lead to an increase of more skilled employees being hired, Jurgenson (2018).

\section{References}

Alcacer J, \& Oxley, J. E. (2014). Learning by supplying. Harvard Business School Strategy Unit Working Paper. 35(2):204-223

Altenburg, T. (2006). Opportunities for Asian countries to catch up with knowledge-

based competition, in Lundvall, B., Intarakumnerd, P. \& Vang, J. (eds.). Asian's innovation system in transition, Cheltenham: Edward Elgar, 21-53.

Aw, B. Y., Chung, S., \& Roberts, M. J. (2000). Productivity and turnover in the

export market: Micro evidence from Taiwan and South Korea. World Bank Economic Review. 14(1): 65-90.

Basberg, B. L. (1982). Technological change in the Norwegian whaling industry: A case study in the use of patent statistics as a technology indicator. Research Policy, 11(3): 163-171.

Basberg, B. L. (1987). Patents and the measurement of technological change: A survey of the literature. Research Policy, 16(2-4): 131-141.

Blalock, G., \& Gertler, P. J. (2004). Learning from exporting revisited in a less developed setting. Journal of Development Economics. 75(2): 397-416.

Comanor, W. S., \& Scherer, F. M. (1969). Patent statistics as a measure of technical change. The Journal of Political Economy, 77(3): 392-398.

Chandran, V. G. R., Rasiah, R., \& Wad, P. (2009). Malaysian Manufacturing Systems of Innovation and Internationalization of R\&D. Frederiksberg: Centre for Business and Development Studies, CBS.

Crepon, B., Duguet, E., \& Mairesse, J. (1998). Research, Innovation and

Productivity: An Econometric Analysis at the Firm Level. NBER Working Paper. 6696.

Crino, R., \& Epifani, P. (2012). Productivity, Quality and Export Behaviour. Economic Journal. 122(565):1206-1243.

Hall, B. H., Jaffe, A. B. \& Trajtenberg, M. (2001). “The NBER Patent Citations

Data File: Lessons, Insights and Methodological Tools.” NBER Working Paper, 8498.

Henderson, R. \& Cockburn, I. (1994). Measuring Competence? Exploring Firm Effects in Pharmaceutical Research. Strategic Management Journal. 15: 63-84.

Henderson, R., \& Cockburn, I. (1996). Scale, scope, and spillovers: The determinants of research productivity in drug discovery. Rand Journal of Economics, 27(1): 32-60.

Jurgenson, H. (2018). The Importance of Patent Ownership in Employment Contracts in Indonesia: A Case Study. Available on: http://www.youripinsider.eu/importance-patent- 
ownership-employment-contracts-indonesia-case-study/. Accessed on: 20 September 2020

Le, N. H. (2015). Innovation and Economic Growth in Malaysia. Lund University.

Lee, C. (2004). The determinants of innovation in the Malaysian manufacturing sector: an econometric analysis at the firm level. ASEAN Econ Bull, 21: 319-329

Lee, C. (2008). Innovation, Productivity and Exports: Firm-Level Evidence from Malaysia. University of Nottingham Malaysia Campus.

Oslo, M. (2005). Guidelines for collecting and interpreting innovation data: OECD,

Ozler, S., \& Yilmaz, K. (2001). Does trade liberalization improve productivity? Plant level evidence from the Turkish manufacturing industry. Working Paper, University of California, Los Angeles.

Rajah, R., \& Yap X. S. (2015). Institutional Support, Regional Trade Linkages and Technological Capabilities in the Semiconductor Industry in Malaysia. Working Papers DP2015-16, Economic Research Institute for ASEAN and East Asia (ERIA).

Salomon, R. M. (2006). Spillovers to foreign market participants: assessing the impact of export strategies on innovative productivity. New York University. 4(2):135-164.

Salomon, R. M. \& Shaver, J. M. (2005). Learning by exporting: new insights from examining firm innovation. J Econ Manag Strategy, 14(2):431-460.

Salomon, R. \& Jin, B. (2008). Does knowledge spill to leaders or laggards? Exploring industry heterogeneity in learning by exporting. Journal of International Business Studies, 39 (1): 132-150.

Scherer, F. M. (1965). Firm size, market structure, opportunity and the output of patented inventions. The American Economic Review, 55(5): 1097-1125.

Yang, C. (2018). Exports and innovation: the role of heterogeneity in exports. Empirical Economics. 55 (3): 1065-1087.

Zhu, L., \& Jeon, B. (2007). International R\&D Spillovers: Trade, FDI, and Information Technology as Spillover Channels. Review of International Economics. 15(5): 955-976.

Zemplinerová, A., \& Hromadkova, E. (2012). Determinants of Firm's Innovation. Prague Economic Papers. 2012(4): 487-503. 